\title{
Shuttleworthia satelles gen. nov., sp. nov., isolated from the human oral cavity
}

Molecular Microbial Ecology Programme, GKT Dental Institute, King's College London, London, UK

\author{
Julia Downes, Mark A. Munson, David R. Radford, David A. Spratt† \\ and William G. Wade
} Author for correspondence: William G. Wade. Tel: +44 207955 2849. Fax: +44 2079552847.
e-mail: william.wade@kcl.ac.uk

Keywords: Shuttleworthia, Eubacterium, systematics, phylogeny

\section{INTRODUCTION}

Historically, the genus Eubacterium has largely been defined by default and, prior to the introduction of taxonomic methods based on phylogeny, contained a large number of heterogeneous species. Recent studies have confirmed the phylogenetic diversity of this group, and a number of new genera have been created for species formerly classified as Eubacterium within both the phyla Actinobacteria (high $\mathrm{G}+\mathrm{C}$ ) and

\footnotetext{
† Present address: Department of Microbiology, Eastman Dental Institute for Oral Health Care Sciences, University College London, 256 Gray's Inn Road, London, UK.

¥Present address: Oral Microbiology, Floor 28, Guy's Tower, Guy's Hospital, London SE1 9RT, UK.

Abbreviations: FAA, Fastidious Anaerobe Agar; PYG, peptone/yeast extract/glucose.

The GenBank accession number for the 16S rRNA gene sequence of Shuttleworthia satelles DSM $14600^{\top}$ (= CCUG $45864^{\top}=$ VPI D143K-13 $)$ is AF399956.
}

Firmicutes (low $\mathrm{G}+\mathrm{C}$ ). These include Slackia (Wade et al., 1999), Eggerthella (Wade et al., 1999), Cryptobacterium (Nakazawa et al., 1999) and Collinsella (Kageyama et al., 1999) within the Actinobacteria and Bulleidia (Downes et al., 2000) and Mogibacterium (Nakazawa et al., 2000) within the low $\mathrm{G}+\mathrm{C}$ group. There remain a number of, as yet, unclassified taxa. Moore et al. (1982, 1983, 1985) identified many of these taxa in studies of the microflora associated with different clinical forms of periodontitis. These taxa were grouped on the basis of phenotypic tests, protein profiles and fatty acid methyl ester analysis. One such group described by Moore and colleagues is Eubacterium D23, nine strains of which were examined in this study.

\section{METHODS}

Bacterial strains. The strains included in the study were originally isolated by W. E. C. Moore and colleagues at the Virginia Polytechnic Institute (VPI) and were kindly donated 
to us by Dr Anne Tanner. Nine strains were studied: strains VPI D027F-10, D082J-12A, D065C-30, D061B-03 and D118B-24A were isolated from periodontal pockets (5$7 \mathrm{~mm}$ deep) in adults with periodontal disease and strains VPI D143K-13 ${ }^{\mathrm{T}}$, D133C-17, D145G-28 and D137H-30 were isolated from subgingival plaque from gingival crevices of probing depth $2-3 \mathrm{~mm}$ from 12- to 14-year-olds in a twin study.

Morphology. Strains were grown at $37^{\circ} \mathrm{C}$ on Fastidious Anaerobe Agar (FAA; LabM) supplemented with 5\% (v/v) horse blood under anaerobic conditions $\left(80 \% \mathrm{~N}_{2}, 10 \% \mathrm{H}_{2}\right.$, $10 \% \mathrm{CO}_{2}$ ). Colonial morphologies were determined using a plate microscope after incubation for up to 10 days. Cellular morphology was recorded after Gram staining of 3-day plate cultures. Hanging-drop preparations of $18 \mathrm{~h}$ cultures of peptone/yeast extract/glucose (PYG) broth were examined by phase-contrast microscopy for cellular motility.

Individual colonies from 10-day FAA plates were removed from the plates together with a block $\left(5 \mathrm{~mm}^{3}\right)$ of agar. The colony and attached agar were placed in $2.5 \%(\mathrm{v} / \mathrm{v})$ glutaraldehyde for $4 \mathrm{~h}$ at $4{ }^{\circ} \mathrm{C}$. Samples were transferred to $10 \%(\mathrm{v} / \mathrm{v})$ ethanol for $10 \mathrm{~min}, 70 \%(\mathrm{v} / \mathrm{v})$ ethanol for $30 \mathrm{~min}$ and then washed three times in $100 \%$ ethanol for $20 \mathrm{~min}$. Samples were placed in a critical point drier (K850; Emitech), mounted onto aluminium stubs using silver colloidal paint (Emitech), sputter-coated with gold (K550; Emitech) and then viewed by scanning electron microscopy (S-3500N; Hitachi).

Ultrastructure. Transmission electron microscopy was used to examine the cell-wall ultrastructure. Cells were fixed in $2.5 \%(\mathrm{v} / \mathrm{v})$ glutaraldehyde in $0.2 \mathrm{M}$ Sorensen's buffer and then washed in the same buffer. The cells were post-fixed in $1 \%(\mathrm{w} / \mathrm{v})$ osmium tetroxide, dehydrated by a graded series of ethanol, treated with propylene oxide and embedded in TAAB epoxy resin. Ultrathin sections were stained with uranyl acetate and lead citrate for transmission electron microscopy (H7600; Hitachi).

Biochemical tests. Fermentation tests were performed using pre-reduced, anaerobically sterilized sugars (Holdeman et al., 1977) except that the pre-reduced, anaerobically sterilized media were prepared in an anaerobic workstation using pre-reduced distilled water. Other biochemical tests were performed as described by Holdeman et al. (1977) and Summanen et al. (1993). Sensitivity to bile was determined by comparing growth of strains on FAA with and without $2 \%(\mathrm{v} / \mathrm{v})$ oxgall after 5 days incubation. Spore formation was assessed by both direct microscopic examination and culture following killing of vegetative cells by heating to $80{ }^{\circ} \mathrm{C}$ for $10 \mathrm{~min}$.

Metabolic end-product analysis. Bacterial strains were grown in PYG broth and short-chain volatile and non-volatile fatty acids were extracted by using standard methods (Holdeman et al., 1977). Analysis was performed by GC with a capillary column coated with CP-Wax 58 stationary phase.

Protein profiles. Protein profiles of whole-cell proteins were generated by SDS-PAGE using 10-15\% gradient gels and the PhastSystem (Pharmacia) as described previously (Slayne et al., 1990), except that the cells were pre-treated with lysozyme $\left(50 \mu \mathrm{g} \mathrm{ml}^{-1}\right)$ for $3 \mathrm{~h}$ at $37^{\circ} \mathrm{C}$ and vortexmixed for 4 min with $0 \cdot 1$ vols $100 \mu \mathrm{m}$ diameter glass beads before boiling.

Enzyme profiles. Enzyme profiles were generated with the Rapid ID32A anaerobe identification kit (bioMérieux) according to the manufacturer's instructions. Bacteria were harvested from blood-agar plates [Blood agar base no. 2 (LabM) supplemented with $5 \%(\mathrm{v} / \mathrm{v})$ horse blood] incubated anaerobically at $37^{\circ} \mathrm{C}$ for $72 \mathrm{~h}$. All strains were tested on at least two occasions.

16S rRNA gene PCR and sequencing. DNA was isolated from the bacteria by standard methods. The 16S rRNA gene was amplified by using a PCR with primers $27 \mathrm{~F}$ and $1492 \mathrm{R}$ (Lane, 1991). PCR amplification was performed with a Uno II thermocycler (Biometra) using PCR buffer (Bioline) containing $1.5 \mathrm{mM} \mathrm{MgCl}, 200 \mu \mathrm{M}$ dNTPs, $1 \mathrm{mM}$ each oligonucleotide primer, 1 U Taq DNA polymerase (Bioline) and template DNA in a total volume of $100 \mu \mathrm{l}$. Thirty amplification cycles were performed using a denaturing temperature of $94^{\circ} \mathrm{C}$ for $1 \mathrm{~min}$, annealing at $54{ }^{\circ} \mathrm{C}$ for $1 \mathrm{~min}$ and elongation at $72^{\circ} \mathrm{C}$ for $2 \mathrm{~min}$. PCR products were sequenced directly using a dye terminator cycle sequencing kit with AmpliTaq FS (Perkin Elmer) and $60 \mathrm{ng}$ template DNA, according to the manufacturer's instructions. Sequencing was performed using an automated sequencer (ABI 377; Perkin Elmer) with primers 27F, 342R, 357F, 519R, 907R, 926F, 1100R, 1114F, 1392R and 1492R (Lane, 1991).

Sequence analysis. Sequences were connected using DNASIS (Hitachi) and then submitted to the Ribosomal Database Project II (Maidak et al., 2001), via the web, for provisional identification using the SEQUENCE_MATCH program. From the phylogenetic position indicated by SEQUENCE_MATCH, related sequences were selected from sequence databases and aligned by means of CLUSTAL X (Thompson et al., 1997). Further analysis was performed using the PHYLIP suite of programs (Felsenstein, 1993). Specifically, DNADIST was used to compare sequences by means of the Jukes-Cantor algorithm and NEIGHBOR was used to construct phylogenetic trees, which were viewed using TREEVIEW (Page, 1996).

Estimation of $\mathbf{G}+\mathbf{C}$ contents of DNAs. The $\mathrm{G}+\mathrm{C}$ contents of DNAs were estimated by using an HPLC method as described previously (Wade et al., 1999).

\section{RESULTS}

Cells were obligately anaerobic, non-spore-forming, non-motile, Gram-positive short bacilli occurring singly, in pairs, short chains and diphtheroid arrangements (Fig. 1a). Many cells were curved, the amount of curvature varying between cells.

The colony morphology was variable, three distinct phenotypes being observable. After 5 days incubation on FAA plates, colonies were, on average, $0.9 \mathrm{~mm}$ in diameter, circular and entire, with a grey, low-convex centre surrounded by a flat, translucent margin. This colony type is designated the A type. Upon further incubation, smaller, satellite colonies (B type) arose on the periphery or within the original colonies (Fig. 2). These satellite colonies were approximately 0.2 $0.3 \mathrm{~mm}$ in diameter, convex, circular, entire, off-white, semi-opaque and shiny. It was not possible to separate colony type B from the primary A type. A third colony type (C) was seen in plate cultures after 6 days incubation. These were irregular, cream-coloured and opaque. Upon subculture, these resulted in colonies approximately $0.6 \mathrm{~mm}$ in diameter, circular, entire, high-convex, cream-coloured and opaque after 5 days incubation. This phenotype was stable upon sub- 

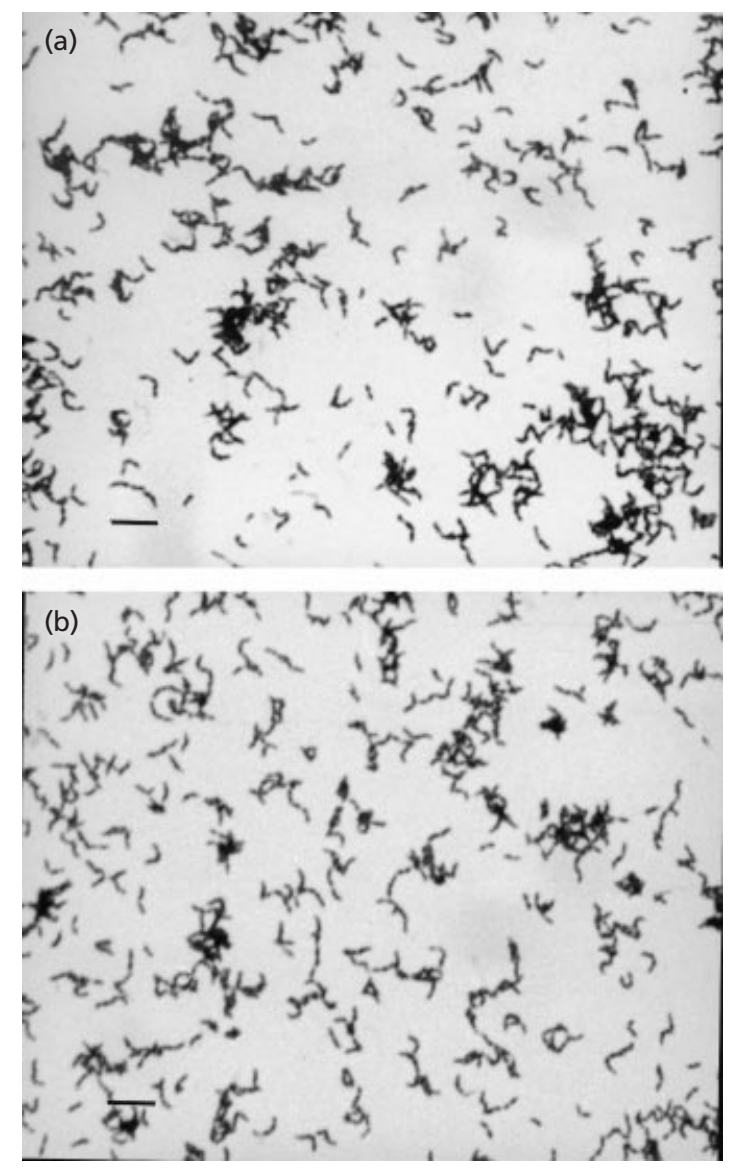

Fig. 1. Cellular morphology of Shuttleworthia satelles gen. nov., sp. nov. D143K $-13^{\top}$ in Gram-stained smear: colony type $A$ (a) and colony type $C$ (b) are shown. Bars, $5 \mu \mathrm{m}$.

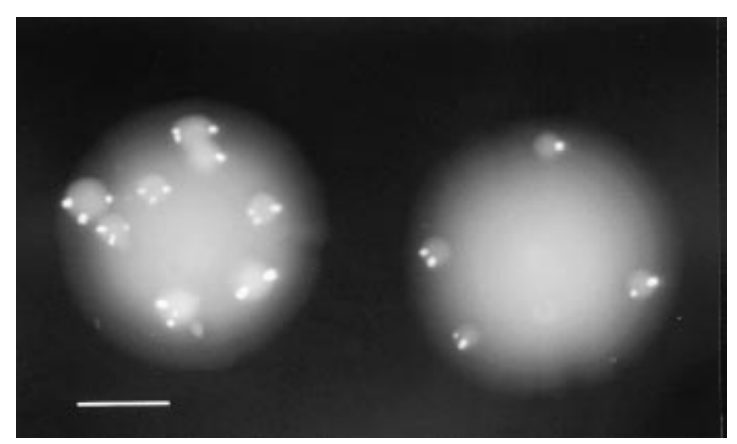

Fig. 2. Colony morphology of 10-day culture of Shuttleworthia satelles gen. nov., sp. nov. D143K-13 ${ }^{\top}$ showing satellite colonies (B type) arising within the primary colonies (A type). Bar, $0.5 \mathrm{~mm}$.

sequent subculture. Gram-staining of cells forming the C-type colony showed their morphology to be identical to those of the A type (Fig. 1b).

Type-A colonies giving rise to the B-type satellite colonies were examined under the scanning electron
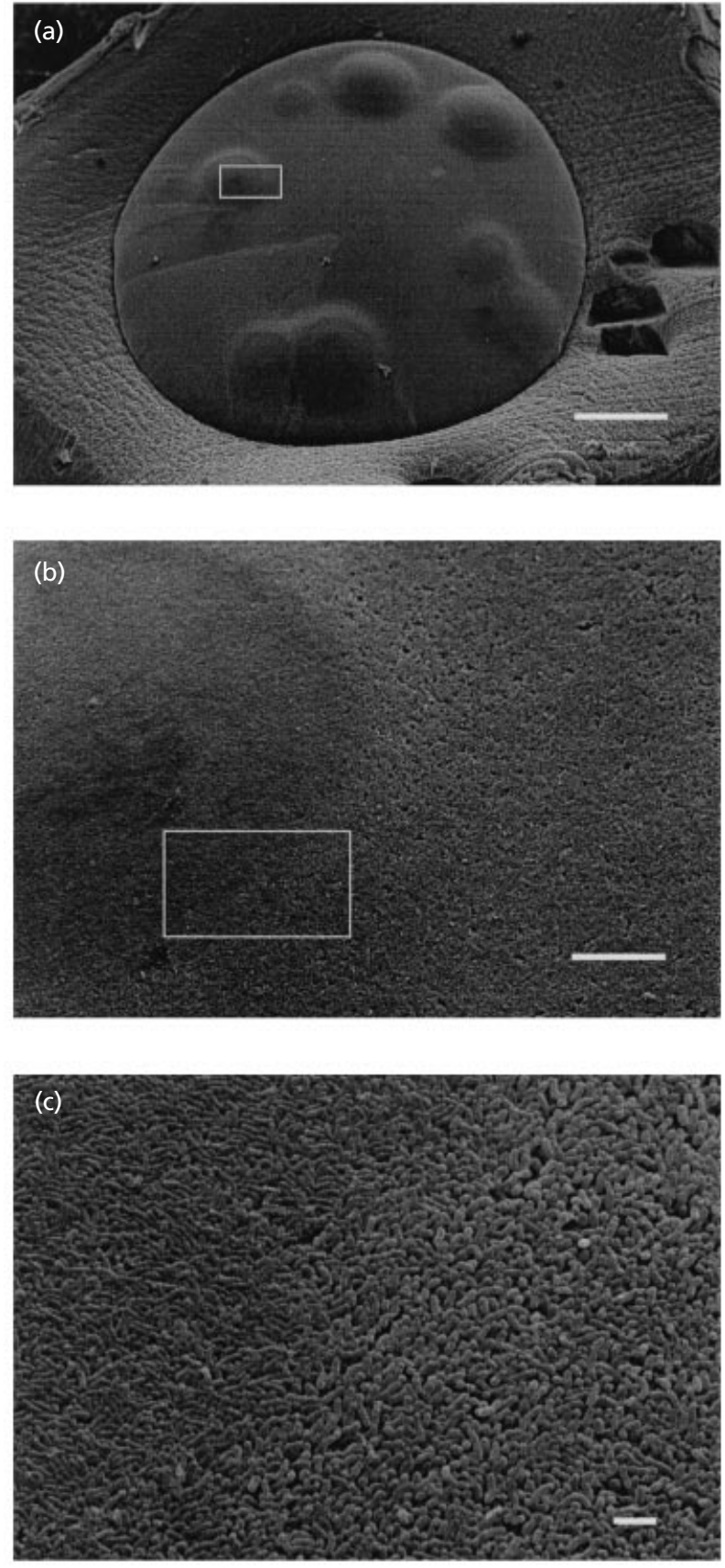

Fig. 3. Scanning electron micrographs of a 10-day culture of a colony of Shuttleworthia satelles gen. nov., sp. nov. D143K-13 on FAA. (a) Entire colony showing primary colony type $A$ with B-type colonies arising within. Bar, $0.2 \mathrm{~mm}$. (b) Area bounded by box in (a). Bar, $0.02 \mathrm{~mm}$. (c) Area bounded by box in (b). Bar, $2 \mu \mathrm{m}$.

microscope to determine if two cellular forms could be seen. Fig. 3(a-c) shows an example of a 10-day-old colony at increasing magnifications. Fig. 3(c) shows the junction between the primary (A) and satelliting (B) colony forms, and it can be seen that the organisms in both regions are of identical cellular morphology, although the cells in the B-type colony are more closely 


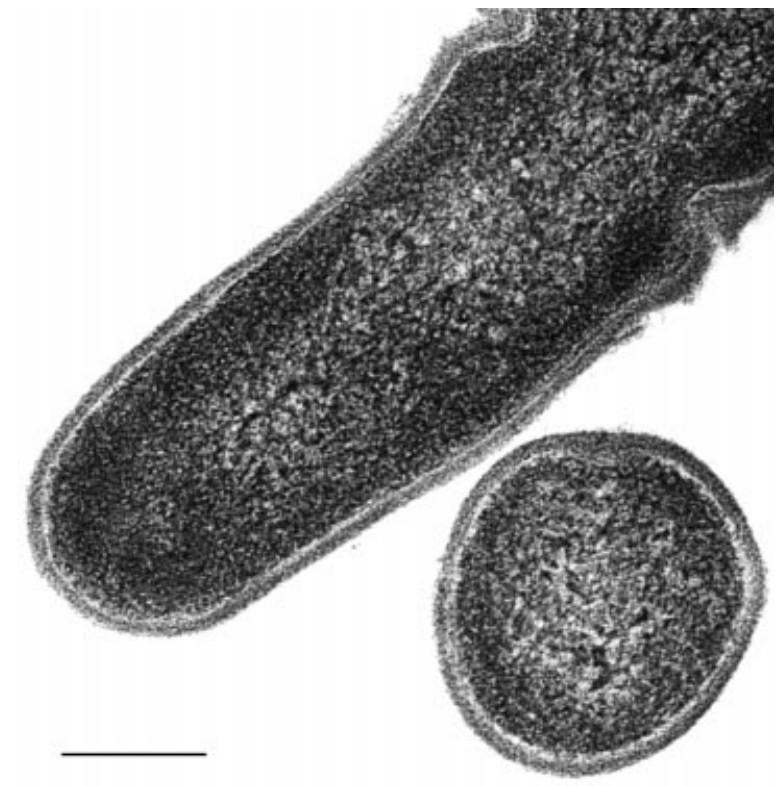

Fig. 4. Transmission electron micrograph of Shuttleworthia satelles gen. nov., sp. nov. D143K-13 ${ }^{\top}$. Ultrathin section showing the Gram-positive cell wall and the cytoplasmic membrane. Bar, $0.2 \mu \mathrm{m}$.

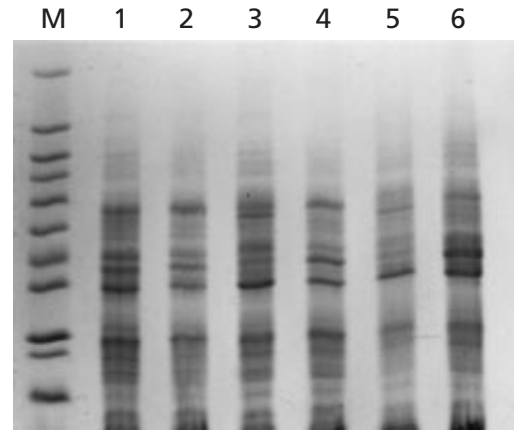

Fig. 5. Protein profiles of Shuttleworthia satelles gen. nov., sp. nov. Lanes: 1, D027F-10, A colony type; 2, D027F-10, C type; 3, D143K-13 ${ }^{\top}$, A type; 4, D143K-13 ${ }^{\top}$, C type; 5, D061B-03, A type; 6, D061B-03, C type; M, molecular mass markers (20.1, 24, 29, $36,45,55,66,84,97 \cdot 4,116$ and $205 \mathrm{kDa})$.

packed. 'Sectoring' of the primary colony can also be seen in Fig. 3(a).

Transmission electron microscopic examination of ultrathin sections through the cells showed the presence of a typical Gram-positive cell wall, approximately $25 \mathrm{~nm}$ thick (Fig. 4).

Protein profiles of $\mathrm{A}$ and $\mathrm{C}$ colony types for strains D027F-10, D143K-13 and D061B-03 are shown in Fig. 5. Overall, the profiles were very similar; there were some differences between strains, but there were no consistent differences between the $\mathrm{A}$ and $\mathrm{C}$ colony types.
Table 1. Biochemical characteristics of Shuttleworthia satelles gen. nov., sp. nov. and separated colonial morphotypic variants

Numbers of strains that tested positive/number tested are shown. For separated colony types, only reactions that differ between colony types are shown.

\begin{tabular}{|lccc|}
\hline Characteristic & $\begin{array}{c}\text { S. satelles } \\
\text { (9 strains) }\end{array}$ & $\begin{array}{c}\text { A colony } \\
\text { (5 strains) }\end{array}$ & $\begin{array}{c}\text { C colony } \\
\text { (5 strains) }\end{array}$ \\
\hline Aesculin hydrolysis & $9 / 9$ & & \\
Arginine hydrolysis & $0 / 9$ & & \\
Bile (20\%) growth & $0 / 9$ & & \\
Catalase & $0 / 9$ & & \\
Gelatin hydrolysis & $0 / 9$ & & \\
H$_{2}$ S production & $0 / 9$ & & \\
Indole production & $9 / 9$ & & \\
Motility & $0 / 9$ & & \\
Nitrate reduction & $0 / 9$ & & \\
Urea hydrolysis & $0 / 9$ & & \\
Fermentation of: & & & \\
Arabinose & $9 / 9$ & $0 / 5$ & \\
Cellobiose & $9 / 9$ & $1 / 5$ & \\
Fructose & $9 / 9$ & & \\
Glucose & $9 / 9$ & & \\
Lactose & $6 / 9$ & $2 / 5$ & \\
Maltose & $9 / 9$ & & \\
Mannitol & $5 / 9$ & & \\
Melezitose & $9 / 9$ & & \\
Melibiose & $9 / 9$ & $0 / 5$ & \\
Rhamnose & $9 / 9$ & & \\
Salicin & $8 / 9$ & $1 / 5$ & \\
Sorbitol & $0 / 9$ & & \\
Sucrose & $9 / 9$ & & \\
Trehalose & $9 / 9$ & & \\
Fermentation end & $\mathrm{a}, \mathrm{b}, 1$ & $\mathrm{a}, \mathrm{b}, 1$ & \\
products* & & & \\
\hline
\end{tabular}

*a, Acetate; b, butyrate; 1 , lactate.

Growth in peptone/yeast extract broth was good. The addition of $1 \%(\mathrm{w} / \mathrm{v})$ fermentable carbohydrates stimulated growth; Tween 80 did not. The biochemical properties of the strains are shown in Table 1, together with a comparison of the results for isolated A- and Ctype colonies. All strains fermented fructose, glucose, maltose, melezitose, rhamnose, sucrose and trehalose, some fermented lactose and mannitol, but none fermented sorbitol. Cells forming the C-type colonies fermented arabinose, cellobiose, melibiose and salicin, while the A colony type of the majority of strains did not. Moderate amounts of acetate, butyrate and lactate were produced as end products of glucose metabolism in PYG. All strains hydrolysed aesculin and produced indole. Nitrate was not reduced and arginine and urea were not hydrolysed. Gelatin was not liquefied and $\mathrm{H}_{2} \mathrm{~S}$ was not produced. There was no growth in $20 \%$ bile. All strains were positive for $\alpha$ galactosidase, $\beta$-galactosidase, $\alpha$-glucosidase, $\beta$-glu- 


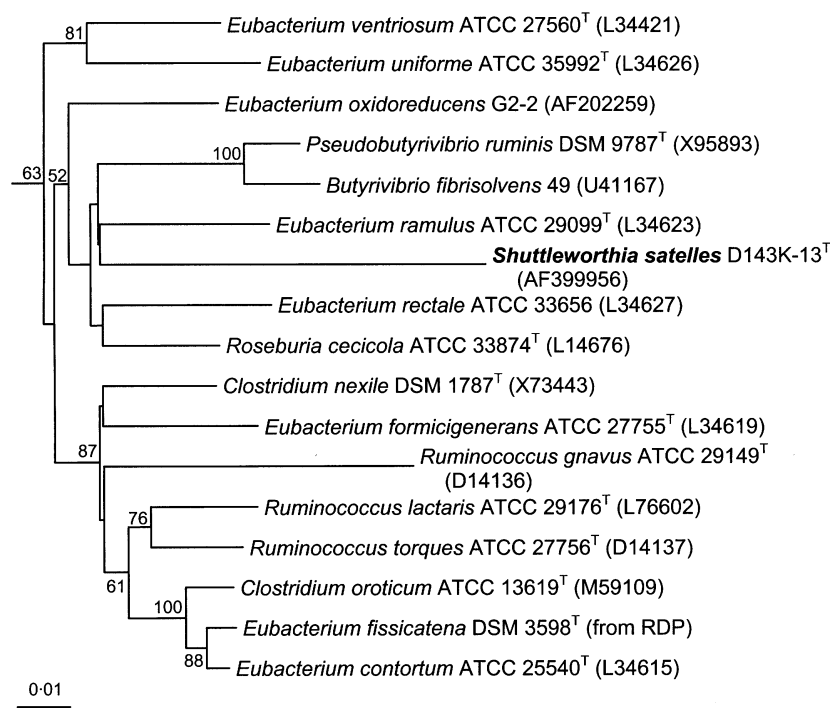

Fig. 6. Phylogenetic tree based on $16 \mathrm{~S}$ rRNA gene sequence comparisons over 1049 aligned bases, showing the relationship between Shuttleworthia satelles gen. nov., sp. nov. and related species. The tree was constructed using the neighbour-joining method following distance analysis of aligned sequences and was rooted for Clostridium aminovalericum. Numbers represent bootstrap values for each branch, based on data for 100 trees. Accession numbers for $16 \mathrm{~S}$ rRNA sequences are given for each strain. Bar, 0.01 nucleotide substitutions per site.

cosidase and indole in the Rapid ID32A identification panel, while reactions for $\beta$-glucuronidase were weak and variable. All strains were negative for the remaining 22 tests, resulting in a Rapid ID32A profile of $45^{1} / 50200000$. Profiles were reproducible for each strain. The $\mathrm{G}+\mathrm{C}$ content of the DNA of strain VPI D $143 \mathrm{~K}-13^{\mathrm{T}}$ was $51 \mathrm{~mol} \%$.

Phylogenetic analysis of the 16S rRNA gene sequence of strain VPI D143K-13 ${ }^{\mathrm{T}}$ placed this organism within the phylum Firmicutes and most closely related to the species Butyrivibrio fibrisolvens (90.8\% 16S rDNA sequence similarity), Pseudobutyrivibrio ruminis $(90 \cdot 1 \%)$, Eubacterium rectale $(90 \cdot 3 \%)$, Eubacterium ramulus $(90 \cdot 2 \%)$ and Roseburia cecicola $(90 \cdot 8 \%)$ (Fig. $6)$. Bootstrap analysis of the dendrogram showed that the branching arrangement of these species should not be relied upon, although they can be confidently assigned to this group as a whole. In addition, approximately 550 bases of $16 \mathrm{~S}$ rDNA were sequenced for strains D027F-10, D082J-12A, D061B-03, D133C17, D118B-24A and D145G-28 between positions 357 and 907 (Escherichia coli numbering). This stretch of sequence includes the variable regions V3-5 (Neefs et al., 1993). Over 453 aligned bases, each strain had $>99 \%$ sequence similarity to each other strain. In addition, DNA was extracted from the $\mathrm{A}$ and $\mathrm{C}$ colony types for strains D143K-13 ${ }^{\mathrm{T}}$, D065C-30 and D133C17 and the 16S rRNA gene was sequenced over the same region. Over 458 aligned bases, the sequences for the $\mathrm{A}$ and $\mathrm{C}$ colony types were identical for strains
D065C-30 and D133C-17 and differed by one base for strain D143K-13 ${ }^{\mathrm{T}}$.

\section{DISCUSSION}

Phenotypic tests showed the nine strains to constitute a homogeneous group. Phylogenetic analysis of representative strains showed that this taxon constitutes a deep branch within the low $\mathrm{G}+\mathrm{C}$ Gram-positives, most closely related to Butyrivibrio fibrisolvens, Pseudobutyrivibrio ruminis, Eubacterium rectale, Eubacterium ramulus and Roseburia cecicola. However, the 16S rDNA sequence showed less than $91 \%$ similarity to these species, indicating that this taxon represents a novel genus and species, for which we propose the name Shuttleworthia satelles gen. nov., sp. nov. Shuttleworthia satelles, in common with all the species listed above, was saccharolytic, produced butyric acid as a by-product of fermentation and showed some degree of growth stimulation in the presence of fermentable carbohydrates in broth media. The curved morphology of Shuttleworthia satelles cells was also similar to that of these related species, with the exception of Eubacterium ramulus, which has regular, straight bacilli (Moore et al., 1976). Characteristics that distinguish Shuttleworthia satelles from these closely related species are listed in Table 2 . Although strains of Butyrivibrio fibrisolvens stain Gram-negative, they have been shown to have a Grampositive ultrastructure with a very thin wall (Bryant, 1986).

The appearance of the satellite colonies arising from the primary colonial form resembled that of a contaminating organism depending for growth on the primary colony. However, exactly the same appearance was seen in all nine strains, discounting this possibility. Furthermore, the scanning electron micrographs revealed that the morphology of cells in the two colony forms was identical. The sectoring apparent within the colonies was also of interest. This phenomenon is known to arise from spontaneous chromosomal rearrangement during growth, and has been described in Pseudomonas tolaasii, in which the duplication of a $661 \mathrm{bp}$ element was shown to be responsible (Han et al., 1997). It is also interesting that the A and C colony types of Shuttleworthia satelles exhibited different patterns of sugar fermentation. It is possible that a chromosomal rearrangement, responsible for the change in colony morphology, also disrupted genes encoding sugar-fermentation enzymes. 16S rDNA sequence analysis revealed no differences between the cells forming the A and C colony types. We are therefore confident that a single organism is responsible for the formation of the three colony types.

\section{Description of Shuttleworthia gen. nov.}

Shuttleworthia (Shutt.le.wor'thi.a. N.L. n. Shuttleworthia named to honour Cyril Shuttleworth, the distinguished British microbiologist). 
Table 2. Characteristics that distinguish Shuttleworthia satelles from related species

\begin{tabular}{|c|c|c|c|c|c|c|}
\hline Characteristic & Shuttleworthia satelles & Butyrivibrio fibrisolvens & Pseudobutyrivibrio ruminis & Eubacterium rectale & Eubacterium ramulus & Roseburia cecicola \\
\hline Cell shape & Slightly curved & Curved & Curved & Slightly curved & Straight & Slightly curved \\
\hline Gram reaction & + & - & - & $\mathrm{v}$ & + & - \\
\hline Motility & - & + & + & $\mathrm{v}$ & - & + \\
\hline Indole production & + & - & ND & - & - & ND \\
\hline Aesculin hydrolysis & + & $\mathrm{v}$ & ND & + & + & - \\
\hline Fructose fermentation & + & + & + & + & + & - \\
\hline Sorbitol fermentation & - & - & - & $\mathrm{v}$ & $\mathrm{v}$ & + \\
\hline Trehalose fermentation & + & $\mathrm{v}$ & + & $\mathrm{v}$ & - & - \\
\hline Fermentation products* & $\mathrm{a}, \mathrm{B}, 1$ & $\mathrm{~F}, \mathrm{~B}, 1$, (a) & $\mathrm{F}, \mathrm{B}, \mathrm{L}$, (a) & $\mathrm{a}, \mathrm{B}, \mathrm{L},(\mathrm{s})$ & $\mathrm{a}, \mathrm{f}, \mathrm{B}, 1,(\mathrm{~s})$ & B \\
\hline DNA G $+\mathrm{C}$ content $(\mathrm{mol} \%)$ & $50-51$ & 41 & $40-41$ & 38 & 39 & 42 \\
\hline Habitat & Human oral cavity & $\begin{array}{l}\text { Rumen of ruminants; } \\
\text { human, rabbit, horse faeces }\end{array}$ & Cow rumen & Human faeces and colon & Human faeces & Mouse caecum \\
\hline Reference & This paper & Bryant (1986) & van Gylswyk et al. (1996) & $\begin{array}{l}\text { Moore \& Holdeman } \\
\text { Moore (1986) }\end{array}$ & Moore et al. (1976) & Stanton \& Savage (1983) \\
\hline
\end{tabular}

*a, Acetate; f, formate; b, butyrate; l, lactate; s, succinate; (), strain variation or trace amounts detected. Capital letters indicate major products.

ND, Not determined; v, strain variation.

Cells are obligately anaerobic, non-spore-forming, non-motile, slightly curved, Gram-positive, short bacilli. Cells are saccharolytic, and the principal end products of glucose metabolism are acetate, butyrate and lactate. Growth in broth media is good and is stimulated in the presence of fermentable carbohydrates. Aesculin is hydrolysed and indole is produced. Nitrate is not reduced; arginine and urea are not hydrolysed. Gelatin is not liquefied and $\mathrm{H}_{2} \mathrm{~S}$ and catalase are not produced. There is no growth in $20 \%$ bile. The $\mathrm{G}+\mathrm{C}$ content of the DNA of $S$. satelles, the only species so far described in this genus, is $51 \mathrm{~mol} \%$. The type species is Shuttleworthia satelles.

\section{Description of Shuttleworthia satelles sp. nov.}

Shuttleworthia satelles (sat.ell'es. L. n. satelles a satellite or attendant upon a distinguished person, referring to the satelliting appearance of older cultures).

The description is based on nine strains isolated from the human oral cavity. Cells are obligately anaerobic, non-spore-forming, non-motile, slightly curved, Gram-positive, short bacilli $(0.4-0.6 \times 1-2.5 \mu \mathrm{m})$, occurring singly, in pairs, as short chains and as diphtheroidal arrangements. The colony morphology is variable and consists of several different phenotypes. After 5 days incubation on FAA plates, colonies are, on average, $0.9 \mathrm{~mm}$ in diameter, circular and entire, with a grey, low-convex centre surrounded by a flat, translucent margin. Upon further incubation, smaller, satellite colonies arise on the periphery and from within the original colonies. The satellite colonies are $0 \cdot 2-0.3 \mathrm{~mm}$ in diameter, high-convex, circular, entire, off-white, opaque and shiny. A further colony type is approximately $0.6 \mathrm{~mm}$ in diameter, circular, entire, high-convex, cream-coloured and opaque after 5 days incubation. Growth in broth media is good and growth supplements are not required. Fructose, glucose, maltose, melezitose, rhamnose, sucrose and trehalose are fermented, some strains ferment lactose and mannitol and sorbitol is not fermented. Cells forming the cream, high-convex colony type ferment arabinose, cellobiose, melibiose and salicin, while those forming the grey, low-convex colony type either do not ferment these sugars, or only a minority of strains do so. There are no other biochemical characteristics that differ between colony types. Moderate amounts of acetate, butyrate and lactate are produced as end products of glucose metabolism in PYG. Aesculin is hydrolysed and indole is produced. Nitrate is not reduced; arginine and urea are not hydrolysed. Gelatin is not liquefied and $\mathrm{H}_{2} \mathrm{~S}$ and catalase are not produced. There is no growth in $20 \%$ bile. The Rapid ID 32A profile is $45^{1} /{ }_{5} 0200000$. The $\mathrm{G}+\mathrm{C}$ content of the DNA of the type strain is $51 \mathrm{~mol} \%$. The type strain is strain DSM $14600^{\mathrm{T}}\left(=\mathrm{CCUG} 45864^{\mathrm{T}}=\right.$ VPI D143K-13 $\left.{ }^{\mathrm{T}}\right)$. Isolated from human subgingival plaque and periodontal pockets in patients with periodontitis.

\section{ACKNOWLEDGEMENTS}

This study was supported by a grant from the Wellcome Trust (ref. 058950). Professor M. Meredith Smith is thanked for assistance with the preparation of the colonial morphology photograph.

\section{REFERENCES}

Bryant, M. P. (1986). Genus IV. Butyrivibrio Bryant and Small 1956, 18, emend. Moore, Johnson and Holdeman 1976, 241 ${ }^{\mathrm{AL}}$. In Bergey's Manual of Systematic Bacteriology, vol. 2, pp. 1376-1379. Edited by P. H. A. Sneath, N. S. Mair, M. E. Sharpe \& J. G. Holt. Baltimore: Williams \& Wilkins.

Downes, J., Olsvik, B., Hiom, S. J., Spratt, D. A., Cheeseman, S. L., Olsen, I., Weightman, A. J. \& Wade, W. G. (2000). Bulleidia extructa gen. nov., sp. nov., isolated from the oral cavity. Int $J$ Syst Evol Microbiol 50, 979-983.

Felsenstein, J. (1993). PHYLIP (Phylogeny Inference Package) version 3.5c. Distributed by the author. Department of Genetics, University of Washington, Seattle, USA.

Han, B., Pain, A. \& Johnstone, K. (1997). Spontaneous duplication of a 661 bp element within a two-component sensor regulator gene causes phenotypic switching in colonies of Pseudomonas tolaasii, cause of brown blotch disease of mushrooms. Mol Microbiol 25, 211-218. 
Holdeman, L. V. H., Cato, E. P. \& Moore, W. E. C. (1977). Anaerobe Laboratory Manual, 4th edn. Blacksburg, VA: Virginia Polytechnic Institute and State University.

Kageyama, A., Benno, Y. \& Nakase, T. (1999). Phylogenetic and phenotypic evidence for the transfer of Eubacterium aerofaciens to the genus Collinsella as Collinsella aerofaciens gen. nov., comb. nov. Int $J$ Syst Bacteriol 49, 557-565.

Lane, D. J. (1991). 16S/23S rRNA sequencing. In Nucleic Acid Techniques in Bacterial Systematics, pp. 115-175. Edited by E. Stackebrandt \& M. Goodfellow. Chichester: Wiley.

Maidak, B. L., Cole, J. R., Lilburn, T. G. \& 7 other authors (2001). The RDP-II (Ribosomal Database Project). Nucleic Acids Res 29, 173-174.

Moore, W. E. C. \& Holdeman Moore, L. V. (1986). Genus Eubacterium Prévot 1938, 294 ${ }^{\mathrm{AL}}$. In Bergey's Manual of Systematic Bacteriology, vol. 2, pp. 1353-1373. Edited by P. H. A. Sneath, N. S. Mair, M. E. Sharpe \& J. G. Holt. Baltimore: Williams \& Wilkins.

Moore, W. E. C., Johnson, J. L. \& Holdeman, L. V. (1976). Emendation of Bacteroidaceae and Butyrivibrio and descriptions of Desulfomonas gen. nov. and ten new species in the genera Desulfomonas, Butyrivibrio, Eubacterium, Clostridium, and Ruminococcus. Int J Syst Bacteriol 26, 238-252.

Moore, W. E. C., Holdeman, L. V., Smibert, R. M., Hash, D. E., Burmeister, J. A. \& Ranney, R. R. (1982). Bacteriology of severe periodontitis in young adult humans. Infect Immun 38, 1137-1148.

Moore, W. E. C., Holdeman, L. V., Cato, E. P., Smibert, R. M. Burmeister, J. A. \& Ranney, R. R. (1983). Bacteriology of moderate (chronic) periodontitis in mature adult humans. Infect Immun 42, 510-515.

Moore, W. E. C., Holdeman, L. V., Cato, E. P., Smibert, R. M., Burmeister, J. A., Palcanis, K. G. \& Ranney, R. R. (1985). Comparative bacteriology of juvenile periodontitis. Infect Immun $\mathbf{4 8}$, 507-519.

Nakazawa, F., Poco, S. E., Ikeda, T., Sato, M., Kalfas, S., Sundqvist, G. \& Hoshino, E. (1999). Cryptobacterium curtum gen. nov., sp. nov., a new genus of Gram-positive anaerobic rod isolated from human oral cavities. Int J Syst Bacteriol 49, 1193-1200.
Nakazawa, F., Sato, M., Poco, S. E., Hashimura, T., Ikeda, T., Kalfas, S., Sundqvist, G. \& Hoshino, E. (2000). Description of Mogibacterium pumilum gen. nov., sp. nov. and Mogibacterium vescum gen. nov., sp. nov., and reclassification of Eubacterium timidum (Holdeman et al. 1980) as Mogibacterium timidum gen. nov., comb. nov. Int J Syst Evol Microbiol 50, 679-688.

Neefs, J. M., Van de Peer, Y., De Rijk, P., Chapelle, S. \& De Wachter, R. (1993). Compilation of small ribosomal subunit RNA structures. Nucleic Acids Res 21, 3025-3049.

Page, R. D. M. (1996). TreeView: an application to display phylogenetic trees on personal computers. Comput Appl Biosci 12, 357-358.

Slayne, M. A., Aldred, M. J. \& Wade, W. G. (1990). A rapid, semiautomated SDS-PAGE identification system for oral anaerobic bacteria. J Appl Bacteriol 68, 391-395.

Stanton, T. B. \& Savage, D. C. (1983). Roseburia cecicola gen. nov., sp. nov., a motile, obligately anaerobic bacterium from a mouse cecum. Int J Syst Bacteriol 33, 618-627.

Summanen, P., Baron, E. J., Citron, D. M., Strong, C. A., Wexler, H. M. \& Finegold, S. M. (1993). Wadsworth Anaerobic Bacteriology Manual, 5th edn. Belmont, CA: Star Publishing.

Thompson, J. D., Gibson, T. J., Plewniak, F., Jeanmougin, F. \& Higgins, D. G. (1997). The CLUSTAL_X windows interface: flexible strategies for multiple sequence alignment aided by quality analysis tools. Nucleic Acids Res 25, 4876-4882.

van Gylswyk, N. O., Hippe, H. \& Rainey, F. A. (1996). Pseudobutyrivibrio ruminis gen. nov., sp. nov., a butyrate-producing bacterium from the rumen that closely resembles Butyrivibrio fibrisolvens in phenotype. Int J Syst Bacteriol 46, 559-563.

Wade, W. G., Downes, J., Dymock, D., Hiom, S. J., Weightman, A. J., Dewhirst, F. E., Paster, B. J., Tzellas, N. \& Coleman, B. (1999). The family Coriobacteriaceae: reclassification of Eubacterium exiguum (Poco et al. 1996) and Peptostreptococcus heliotrinreducens (Lanigan 1976) as Slackia exigua gen. nov., comb. nov. and Slackia heliotrinireducens gen. nov., comb. nov., and Eubacterium lentum (Prevot 1938) as Eggerthella lenta gen. nov., comb. nov. Int J Syst Bacteriol 49, 595-600. 